\title{
PENENTUAN KADAR FENOLAT TOTAL DAN AKTIVITAS ANTIOKSIDAN DARI EKSTRAK DAUN DADAP MERAH (Erythrina fusca Lour) SECARA SPEKTROFOTOMETRI UV-Vis
}

\author{
Epi Supri Wardi, Zulkarni R, Desy Nurdianti
}

\author{
Sekolah Tinggi Farmasi Indonesia Yayasan Perintis Padang \\ Email: epi.supriwardi@gmail.com
}

\begin{abstract}
Determination of total phenolate and antioxidant activity of red leaf extract (Erythrina fusca Lour) was done by UV-Vis spectrophotometry. This study aims to determine the total phenolic content and antioxidant activity of hexane, ethyl acetate and ethanol extract. The extracts were prepared using a non-polar-maseration method with hexane, ethyl acetate and ethanol solvents. The results showed total phenolic concentration using the Folin-Ciocalteu method were $0.412 \mathrm{~g} / 100 \mathrm{~g}$ in the hexane extract, $1.782 \mathrm{~g} / 100 \mathrm{~g}$ in the ethyl acetate extract and $5.455 \mathrm{~g} / 100 \mathrm{~g}$ in the ethanol extract. Antioxidant activity conducted by using FRAP method (Ferric Reducing Antioxidant Power) were obtained 0,682 mmol Fe (II)/100 $\mathrm{g}$ at hexane extract, 5,186 mmol Fe (II)/100 $\mathrm{g}$ at ethyl acetate extract and $10,591 \mathrm{mmol} \mathrm{Fe}(\mathrm{II}) / 100 \mathrm{~g}$ on the ethanol extract. The antioxidant activity of gallic acid as standard was $44.356 \mathrm{~g} \mathrm{mmol} \mathrm{Fe}(\mathrm{II}) / 100 \mathrm{~g}$.
\end{abstract}

Key Words : Erythrina fusca Lour, total phenolate, antioxidant, FRAP, UV-Vis spectrophotometry.

\section{PENDAHULAN}

Indonesia merupakan salah satu negara pengguna tumbuhan obat terbesar di dunia. Hal ini sangat erat kaitannya dengan kekayaan sumber alam yang dimiliki. ${ }^{1}$ Salah satu tumbuhan obat yang digunakan masyarakat Indonesia adalah dadap merah (Erythrina fusca Lour).Tumbuhan dadap merah (Erythrina fusca Lour) telah lama digunakan sebagai obat tradisional untuk mengobati gabak, cacar air, gatal-gatal, pedih, ASI kurang lancar. ${ }^{2}$ Kandungan yang terdapat dalam tumbuhan ini antara lain adalahsaponin, polifenol, dan flavonoid. ${ }^{3}$

Senyawa fenolat merupakan senyawa turunan fenol yang mempunyai aktivitas sebagai antioksidan. Senyawa fenolat bekerja sebagai antioksidan dengan cara mencegah pembentukan radikal bebas baru, yaitu dengan mengubah radikal bebas yang ada menjadi molekul yang tidak mempunyai dampak negatif, bekerja sebagai penangkap radikal bebas, dan mencegah terjadinya reaksi berantai. $^{4}$

Radikal bebas merupakan suatu molekul yang memiliki elektron yang tidak berpasangan dalam orbital terluarnya sehingga menjadi senyawa yang sangat reaktif terhadap sel tubuh dengan cara mengikat elektron molekul sel. ${ }^{5}$ Meskipun manusia telah memiliki sistem pertahanan terhadap radikal bebas, tetapi masih kurang akibat pengaruh lingkungan dan diet yang buruk. Sehingga radikal bebas yang terbentuk tidak lagi diimbangi oleh produksi antioksidan. Hal ini membuat tubuh memerlukan antioksidan eksogen yang dapat diperoleh dari buah dan sayuran yang mampu menangkap radikal bebas. ${ }^{6}$

Antioksidan merupakan senyawa atau molekul yang dapat mencegah terjadinya proses oksidasi. ${ }^{7}$ Antioksidan sintetik seperti 
Penentuan kadar fenolat total dan aktivitas antioksidan dari ekstrak daun dadap merah (Erythrina fusca Lour) secara Spektrofotometri Uv-Vis

BHT (butylated hydroxytoluen), BHA (butylated hydroxyanisole), dan TBHQ (tertbutylhydroxy quinone) dan propil gallate (PG) merupakan senyawa yang telah digunakan selama bertahun-tahun, namun senyawa tersebut sedang diperiksa untuk kemungkinan efek toksisitasnya. Oleh karena itu, sekarang ini dilakukan penelitian intensif tentang antioksidan polifenol alami yang berasal dari tumbuhan untuk menggantikan antioksidan sintetis. $^{8}$

Senyawa fenolat pada tumbuhan dadap merah tidak hanya ada pada daun, tetapi terdapat juga pada bagian lainnya seperti akar dan batang. ${ }^{3}$ Berdasarkan penelitian sebelumnya, tumbuhan ini memiliki aktivitas dalam penghambatan angiogenesis ekstrak etanol daun dadap merah pada membran korio alantois embrio ayam (CAM) terinduksi bFGF. ${ }^{9}$

Berdasarkan latar belakang tersebut peneliti ingin menentukan kadar fenolat total dan aktivitas antioksidan dari ekstrak tumbuhan ini terutama daunnya secara spektrofotometri. Ekstrak daun dadap merah diperoleh dengan menggunakan metode maserasi bertingkat (non polar-polar). Pelarut yang digunakan dalam metode maserasi ini adalah heksana, etil asetat, dan etanol. Penentuan kadar fenolat total dari ekstrak daun dadap merah dilakukan menggunakan metode Folin-Ciocalteu dimana merupakan salah satu metode yang cepat dan sederhana dalam menentukan kandungan fenolat total. ${ }^{10}$ Sedangkan aktivitas antioksidan akan diuji dengan menggunakan metode FRAP (Ferric Reducing Antioxidant Power). Kelebihan metode FRAP ini yaitu metodenya murah, reagennya mudah disiapkan dan cukup sederhana dan cepat, serta tidak menggunakan alat khusus untuk menghitung total antioksidan. Metode ini dapat menentukan kandungan antioksidan total dari suatu bahan berdasarkan kemampuan senyawa antioksidan untuk mereduksi ion $\mathrm{Fe}^{3+}$ menjadi $\mathrm{Fe}^{2+}$ sehingga kekuatan antioksidan suatu senyawa dianalogikan dengan kemampuan mereduksi dari senyawa tersebut. ${ }^{11}$

\section{METODE PENELITIAN}

\section{Penyiapan Sampel}

Sampel segar yang diambil di Air Tawar, Padang, Sumatera Barat, sebanyak 2 $\mathrm{kg}$ dicuci bersih dengan air yang mengalir untuk menghilangkan kotoran yang menempel kemudian ditiriskan. Sampel dikeringkan dengan cara diangin-anginkan terlindung dari sinar matahari selama tujuh hari dan di blender.

\section{Evaluasi Serbuk Sampel}

\section{Pemeriksaan Organoleptis}

Untuk mengetahui karakteristik serbuk sampel, maka identifikasi dilakukan dengan cara pengamatan secara visual meliputi bentuk, warna, dan bau serbuk sampel. ${ }^{12}$

\section{Susut Pengeringan}

Serbuk sampel ditimbang seksama 1 gram dan dimasukkan kedalam krus bertutup yang sebelumnya dipanaskan pada suhu $105^{\circ} \mathrm{C}$ dan ditara. Ratakan serbuk sampel dalam krus, kemudian dimasukkan kedalam oven, dibuka tutupnya, dikeringkan pada suhu $105^{\circ} \mathrm{C}$ hingga bobot tetap. Sebelum setiap pengeringan, dibiarkan krus dalam keadaan tertutup mendingin di dalam desikator hingga suhu ruang. ${ }^{12}$

\section{Pembuatan Ekstrak}

Sebanyak $200 \mathrm{~g}$ simplisia dimaserasi menggunakan pelarut heksana dengan memasukkan 2 liter pelarut ke dalam masing- 
Penentuan kadar fenolat total dan aktivitas antioksidan dari ekstrak daun dadap merah (Erythrina fusca Lour) secara Spektrofotometri Uv-Vis

masing wadah yang telah berisi simplisia.

Rendam selama 6 jam pertama sambil sekalisekali diaduk, lalu diamkan selama 18 jam. Ampas dipisahkan dengan cara disaring menggunakan kertas saring. Proses penyarian diulangi dua kali dengan jumlah pelarut yang sama. Kemudian ampasnya dimaserasi kembali dengan 2 liter etil asetat sambil sekalisekali diaduk selama 6 jam, kemudian didiamkan selama 18 jam. Ampas dipisahkan kemudian di maserasi kembali dengan pelarut etanol dengan prosedur yang sama. Filtrat yang telah terkumpul diuapkan dengan uap vakum (rotary evaporator) hingga diperoleh ekstrak kental. ${ }^{12}$

\section{Pembuatan Larutan}

Pembuatan Larutan Induk Asam Galat $(5000 \mu \mathrm{g} / \mathrm{mL})$

Asam galat ditimbang seksama 0,2510 g, lalu ditambahkan $5 \mathrm{~mL}$ etanol $96 \%$, dicukupkan dengan aquadest hingga $50 \mathrm{~mL} .{ }^{13}$

Pembuatan Larutan Natrium Karbonat 7\%

Ditimbang seksama $7,0003 \mathrm{~g}$ natrium karbonat ditambah $80 \mathrm{~mL}$ aquadest, kemudian didihkan sampai serbuk natrium karbonat larut sempurna. Setelah itu didiamkan selama 24 jam, disaring dan diencerkan dengan aquadest sampai volume $100 \mathrm{~mL}$.

Pembuatan Larutan Induk Besi (II) Sulfat Heptahidrat $10 \mathrm{mmol} / \mathrm{L}$

Besi (II) sulfat heptahidrat ditimbang 0,2781 g dengan seksama kemudian dilarutkan dengan aquadest hingga $100 \mathrm{~mL}$ dalam labu ukur.

\section{Pembuatan Reagen Ferric Reducing Antioxidant Power (FRAP)}

Dicampurkan $10 \mathrm{~mL}$ buffer asetat 0,3 $\mathrm{M}(\mathrm{pH} \mathrm{3,6)}$ dengan $1 \mathrm{~mL}$ larutan o-fenantrolin $10 \mathrm{mmol} / \mathrm{L}$ dan $1 \mathrm{~mL}$ besi (III) klorida heksahidrat $20 \mathrm{mmol} / \mathrm{L}$ ke dalam labu ukur, kemudian tambahkan aquadest hingga tepat $100 \mathrm{~mL}^{.14}$

\section{Pembuatan Larutan Uji}

\section{Penyiapan Larutan Uji Sampel}

Ditimbang seksama 0,5036 g ekstrak heksana, 0,1255 g ekstrak etil asetat dan 0,0539 g etanol, dilarutkan masing-masing dengan pelarut dalam labu ukur $25 \mathrm{~mL}$.

\section{Penyiapan Larutan Uji Asam Galat}

Ditimbang saksama $0,0251 \mathrm{~g}$ asam galat ditambahkan $1 \mathrm{~mL}$ etanol $96 \%$ lalu tambahkan aquadest sampai $25 \mathrm{~mL}$.

\section{Penentuan Panjang Gelombang Serapan} Maksimum

\section{Penentuan PanjangGelombang Serapan}

Maksimum Asam Galat dengan Folin-

Ciocalteu

Panjang gelombang serapan maksimum diperoleh melalui pengukuran absorban dari larutan standar asam galat dengan konsentrasi $200 \mu \mathrm{g} / \mathrm{mL}$. Dipipet 0,9 mL aquadest ke dalam tabung reaksi, lalu ditambahkan 0,1 $\mathrm{mL}$ larutan standar, ditambah $0,5 \mathrm{~mL}$ reagen Folin-Ciocalteu, dikocok, didiamkan selama 5 menit. Kemudian ditambah 2,5 $\mathrm{mL}$ larutan natrium karbonat 7 $\%$, dikocok homogen. Didiamkan selama 26 menit pada suhu kamar. ${ }^{15}$ Lalu ditentukan panjang gelombang serapan maksimum menggunakan spektrofotometer UV-Vis dalam rentang 400-800 nm.

\section{Penentuan Panjang Gelombang Serapan \\ Maksimum Larutan Besi (II) Sulfat Heptahidrat $10 \mathrm{mmol} / \mathrm{L}$}

Larutan standar besi (II) sulfat heptahidrat $10 \mathrm{mmol} / \mathrm{L}$ dipipet sebanyak 0,5 $\mathrm{mL}$ kedalam tabung reaksi yang telah berisi 5 $\mathrm{mL}$ dapar asetat $0,3 \mathrm{M} \mathrm{pH} 3,6$, lalu ditambahkan 0,5 $\mathrm{mL}$ larutan o-fenantrolin 10 $\mathrm{mmol} / \mathrm{L}$. Didiamkan larutan selama 30 menit di 
Penentuan kadar fenolat total dan aktivitas antioksidan dari ekstrak daun dadap merah (Erythrina fusca Lour) secara Spektrofotometri Uv-Vis

tempat gelap, kemudian ditentukan panjang gelombang serapan maksimumnya menggunakan spektrofotometer UV-Vis dalam rentang 400-800 nm. ${ }^{16}$

\section{Penentuan Kurva Kalibrasi \\ Penentuan Kurva Kalibrasi Larutan Asam Galat}

Dari larutan induk asam galat 5000 $\mu \mathrm{g} / \mathrm{mL}$ dibuat seri konsentrasi 50, 100, 150, 200, 250 dan $300 \mu \mathrm{g} / \mathrm{mL}$, sehingga yang dipipet ke dalam labu ukur $25 \mathrm{~mL}$ masingmasing sebanyak 0,$25 ; 0,5 ; 0,75 ; 1 ; 1,25$ dan $1,5 \mathrm{~mL}$ dicukupkan masing-masingnya dengan aquadest sampai tanda batas. Dari masing-masing konsentrasi diatas dipipet 0,1 $\mathrm{mL}$ tambahkan ke dalam tabung reaksi yang telah berisi $0,9 \mathrm{~mL}$ aquadest lalu ditambah 0,5 $\mathrm{mL}$ reagen Folin-Ciocalteu kocok. Diamkan selama 5 menit tambah 2,5 $\mathrm{mL}$ larutan natrium karbonat $7 \%$ kocok homogen. Diamkan selama 26 menit pada suhu kamar lalu ukur pada panjang gelombang serapan maksimum $767,0 \mathrm{~nm}$.

Penentuan Kurva Kalibrasi Larutan Besi (II) Sulfat Heptahidrat

Larutan standar besi (II) sulfat heptahidrat $10 \mathrm{mmol} / \mathrm{L}$ dibuat seri konsentrasi 0,$1 ; 0,2 ; 0,4 ; 0,6 ;$ dan $0,8 \mathrm{mmol} / \mathrm{L}$, sehingga yang dipipet ke dalam labu ukur $25 \mathrm{~mL}$ masing-masing sebanyak 0,$25 ; 0,5 ; 1 ; 1,5$ dan $2 \mathrm{~mL}$ dicukupkan masing-masingnya dengan aquadest sampai tanda batas. Dari masing-masing konsentrasi diatas dipipet 0,5 $\mathrm{mL}$, tambahkan $0,5 \mathrm{~mL}$ ortho-fenantrolin dan kemudian masukkan dalam tabung reaksi yang telah berisi $5 \mathrm{~mL}$ larutan dapar asetat 0,3 $\mathrm{M}(\mathrm{pH} 3,6)$. Siapkan juga larutan blanko tanpa mengandung larutan standar besi (II) sulfat heptahidrat. Biarkan larutan selama 30 menit di tempat gelap dan catat absorban pada panjang gelombang $511 \mathrm{~nm}$.

Penetapan Kadar Fenolat Total dan Aktivitas Antioksidan

Penetapan Kadar Fenolat Total dengan Metode Folin-Ciaocalteu

Sebanyak $0,1 \mathrm{~mL}$ larutan uji ditambahkan ke dalam tabung reaksi yang telah berisi $0,9 \mathrm{~mL}$ aquadest kemudian ditambah $0,5 \mathrm{~mL}$ reagen Folin-Ciocalteu, dikocok. Didiamkan selama 5 menit, lalu ditambahkan 2,5 mL larutan natrium karbonat $7 \%$ kedalam campuran dan dikocok homogen. Didiamkan selama 26 menit pada suhu kamar. ${ }^{15}$ Diukur serapannya dengan spektrofotometer UV-Vis pada panjang gelombang serapan maksimum 767,0 nm.

\section{Penentuan Aktivitas Antioksidan dengan Metode FRAP}

Larutan uji sebanyak $0,1 \mathrm{~mL}$ dan 0,3 $\mathrm{mL}$ aquadest ditambahkan ke dalam tabung yang telah berisi $3 \mathrm{~mL}$ reagen FRAP. Campurkan divortek dan didiamkan selama 30 menit di tempat gelap pada suhu ruang. Absorban sampel diukur pada panjang gelombang serapan maksimum 510,5 nm. Larutan blanko yang digunakan adalah larutan reagen FRAP dengan aquadest tanpa larutan uji. Aktivitas antioksidan sampel dinyatakan dalam mmol besi (II) ekuivalen/g ekstrak.

\section{Analisa Data}

Data yang dikumpulkan adalah data primer yang didapatkan dari absorbansi masing-masing larutan pembanding asam galat dan besi (II) sulfat heptahidrat, dibuat dengan kurva kalibrasi dan diperoleh persamaan regresi linear. Untuk menentukan kadar fenolat total dan aktivitas antioksidan dihitung dengan memasukkan kedalam 
Penentuan kadar fenolat total dan aktivitas antioksidan dari ekstrak daun dadap merah (Erythrina fusca Lour) secara Spektrofotometri Uv-Vis

persamaan regresi linear $y=a+b x$, dimana $y$ adalah absorbansi dan $x$ adalah konsentrasi.

Kemudian dimasukkan kedalam rumus :

$\mathrm{KFT}=\frac{\text { Volume sampel uji } \mathrm{x} \frac{\text { konsentrasi }(\mu \mathrm{g} / \mathrm{mL})}{1000000}}{\text { Berat sampel uji }} \times 100$

Nilai fenolat total dinyatakan dalam satuan gram dalam 100 gram.

$\mathrm{AA}=\frac{\text { Volume sampel uji } \mathrm{x} \frac{\mathrm{konsentrasi}(\mathrm{mmol} / \mathrm{L})}{1000}}{\text { Berat sampel uji }} \times 100$

Nilai aktivitas antioksidan dinyatakan dalam $\mathrm{mmol} \mathrm{Fe} \mathrm{(II)/100} \mathrm{g.}$

\section{HASIL DAN PEMBAHASAN}

Pada penelitian ini telah dilakukan penentuan kadar fenolat total dan aktivitas antioksidan dari ekstrak daun dadap merah (Erythrina fusca Lour) yang diambil di daerah Air Tawar Timur, Padang Utara, Kota Padang, Sumatera Barat. Telah dilakukan identifikasi tumbuhan di Herbarium ANDA Jurusan Biologi Fakultas MIPA Universitas Andalas yang menyatakan bahwa sampel merupakan famili Fabaceae dengan spesies Erythrina fusca Lour. Daun dadap merah yang digunakan sebanyak $2 \mathrm{~kg}$ dan telah dibersihkan agar tidak ada pengotor yang kemudian dikering anginkan dan dibuat menjadi serbuk. Proses pengeringan dilakukan di dalam ruangan. Pembuatan sampel kering menjadi serbuk bertujuan untuk memperluas permukaan sampel. Semakin luas permukaan partikel sampel maka semakin mudah pelarut berpenetrasi ke dalam sampel sehingga dapat mempercepat proses pelarutan dan memperbanyak penarikan senyawa-senyawa yang terkandung di dalam sampel ke dalam pelarut yang digunakan. Proses pengeringan 2 $\mathrm{kg}$ daun dadap merah didapatkan sebanyak $550 \mathrm{~g}$ simplisia. Pemeriksaan organoleptis yang dilakukan pada simplisia didapatkan bahwa bentuknya adalah serbuk, berwarna hijau, dan memiliki aroma yang khas.

Pengukuran susut pengeringan dilakukan pada simplisia. Susut pengeringan merupakan pengukuran sisa zat setelah pengeringan pada temperature $105^{\circ} \mathrm{C}$ hingga didapatkan berat konstan, tujuannya adalah untuk memberikan batasan maksimal atau rentang tentang besarnya senyawa yang hilang selama proses pengeringan. Susut pengeringan pada simplisia adalah $0,061 \%$.

Proses ekstraksi yang dilakukan adalah dengan cara maserasi bertingkat. Cara maserasi dipilih karena pengerjaannya dan peralatannya mudah serta sederhana. Pelarut yang digunakan untuk ekstraksi adalah heksana, etil asetat dan etanol 96\%. Hasil maserasi yang diperoleh kemudian diuapkan dengan rotary evaporatorsehingga didapatkan ekstrak kental. Jumlah simplisia yang diekstraksi adalah sebanyak $200 \mathrm{~g}$ dan menghasilkan 3,8251 g ekstrak kental heksana sehingga didapatkan rendemen ekstrak sebesar 1,913\%. Pada ekstrak etil asetat menghasilkan 7,2485 g ekstrak kental dengan rendemen ekstrak $3,624 \%$ dan pada ekstrak etanol menghasilkan 4,7968 g ekstrak kental dengan rendemen ekstrak 2,398\%. Pada pemeriksaan organoleptis ekstrak heksana, etil asetat dan etanol daun dadap merah diketahui bahwa bentuk ekstrak adalah kental, berwarna coklat kehitaman, dan memiliki bau yang khas. Pada uji kualitatif fenolat dengan larutan $\mathrm{FeCl}_{3}$ 1\% pada ekstrak heksana, etil asetat dan etanol menunjukkan hasil positif yaitu coklat.

Sebelum dilakukan penentuan kadar fenolat total yang dilakukan dengan menggunakan metode Folin-Ciocalteu, terlebih dahulu dilakukan pengukuran panjang 
Penentuan kadar fenolat total dan aktivitas antioksidan dari ekstrak daun dadap merah (Erythrina fusca Lour) secara Spektrofotometri Uv-Vis

gelombang serapan maksimum. Hal ini dilakukan untuk menentukan pada panjang gelombang berapa asam galat dengan reagen Folin-Ciocalteu memberikan serapan yang paling tinggi. Pada penentuan panjang gelombang serapan maksimum ini digunakan larutan asam galat dengan konsentrasi 200 $\mu \mathrm{g} / \mathrm{mL}$. Dari hasil pembacaan spektrofotometri Uv-Vis pada panjang gelombang 400-800 nm memberikan serapan 0,615 dan didapatkan panjang gelombang serapan maksimum 767,0 $\mathrm{nm}$.

Linearitas merupakan ukuran
seberapa baik kurva kalibrasi yang
menghubungkan antara respon $(\mathrm{Y})$ dengan konsentrasi $(X)$. Pada penentuan linearitas dilakukan pengukuran absorban asam galat dengan konsentrasi $50 \mu \mathrm{g} / \mathrm{mL}, 100 \mu \mathrm{g} / \mathrm{mL}, 150$ $\mu \mathrm{g} / \mathrm{mL}, 200 \mu \mathrm{g} / \mathrm{mL}, 250 \mu \mathrm{g} / \mathrm{mL}$ dan $300 \mu \mathrm{g} / \mathrm{mL}$. Pengukuran absorban dari asam galat ini berguna dalam menentukan konsentrasi fenolat total sampel dengan menggunakan persamaan regresi dari kurva kalibrasi dengan persamaan regresi $y=0,0032 x+0,0603$ dengan nilai koefisien korelasi $r=0,9987$. Nilai $r$ yang mendekati 1 membuktikkan bahwa persamaan regresi tersebut adalah linear.

Penentuan kadar fenolat total, larutan uji dibuat dengan konsentrasi tertentu yang absorbannya berada dalam garis linear kurva kalibrasi yaitu pada konsentrasi $20.144 \mu \mathrm{g} / \mathrm{mL}$ untuk ekstrak heksana, $5020 \mu \mathrm{g} / \mathrm{mL}$ untuk ekstrak etil asetat dan $1078 \mu \mathrm{g} / \mathrm{mL}$ untuk ekstrak etanol. Pada penentuan kadar fenolat total ekstrak heksana daun dadap merah didapatkan bahwa ekstrak heksana daun dadap merah memiliki kadar fenolat total sebesar 0,412 $\mathrm{g} / 100 \mathrm{~g}$, ekstrak etil asetat memiliki kadar fenolat total sebesar 1,782 $\mathrm{g} / 100 \mathrm{~g}$ dan ekstrak etanol memiliki kadar fenolat total $5,455 \mathrm{~g} / 100 \mathrm{~g}$. Dari ketiga ekstrak tersebut, ekstrak etanol memiliki kadar fenolat total tertinggi kemudian diikuti dengan ekstrak etil asetat, dan ekstrak heksana.

Selain penentuan kadar fenolat total, pada penelitian ini juga dilakukan penentuan aktivitas antioksidan pada ekstrak heksana, etil asetat dan etanol daun dadap merah. Aktivitas antioksidan dari masing-masing ekstrak daun dadap merah ditentukan dengan menggunakan metode FRAP (Ferric Reducing Antioxidant Power) yang telah dimodifikasi. Prinsip dari metode ini adalah berdasarkan kemampuan senyawa antioksidan mereduksi ion $\mathrm{Fe}$ (III) menjadi Fe (II) dengan membentuk kompleks berwarna jingga-merah yang intensitas warnanya tidak bergantung pada keasaman dalam jangka $\mathrm{pH}$ 2-9, dan stabil dalam waktu yang lama. Asam galat digunakan sebagai pembanding aktivitas antioksidan.

Sebelum dilakukan penentuan aktivitas antioksidan, terlebih dahulu juga dilakukan pengukuran panjang gelombang serapan maksimum besi (II) sulfat heptahidrat dengan reagen o-fenantrolin. Hal ini dilakukan untuk menentukan pada panjang gelombang berapa besi (II) sulfat heptahidrat dengan reagen o-fenantrolin memberikan serapan yang paling tinggi. Pada penentuan panjang gelombang serapan maksimum ini digunakan larutan besi (II) sulfat heptahidrat dengan konsentrasi $10 \mathrm{mmol} / \mathrm{L}$. Dari hasil pembacaan spektrofotometri Uv-Vis pada panjang gelmbang 400-800 nm memberikan serapan 3,594 dan didapatkan panjang gelombang serapan maksimum $511,0 \mathrm{~nm}$.

Pada penentuan linearitas dilakukan pengukuran absorban besi (II) sulfat heptahidrat dengan konsentrasi $0,1 \mathrm{mmol} / \mathrm{L}$, 
Penentuan kadar fenolat total dan aktivitas antioksidan dari ekstrak daun dadap merah (Erythrina fusca Lour) secara Spektrofotometri Uv-Vis

$0,2 \mathrm{mmol} / \mathrm{L}, 0,4 \mathrm{mmol} / \mathrm{L}, 0,6 \mathrm{mmol} / \mathrm{L}$ dan 0,8 $\mathrm{mmol} / \mathrm{L}$. Pengukuran absorban dari besi (II) sulfat heptahidrat dengan reagen o-fenantrolin ini berguna dalam menentukan aktivitas antioksidan sampel dengan menggunakan persamaan regresi dari kurva kalibrasi besi (II) sulfat heptahidrat dengan o-fenantrolin. Dari pengukuran absorban larutan besi (II) sulfat heptahidrat dengan reagen o-fenantrolin didapatkan kurva kalibrasi dengan persamaan regresi $\mathrm{y}=1,116 \mathrm{x}-0,086$ dengan nilai koefisien korelasi $r=0,9960$. Nilai $r$ yang mendekati 1 membuktikan bahwa persamaan regresi tersebut adalah linear.

Penentuan aktivitas antioksidan, larutan uji dibuat dengan konsentrasi tertentu yang absorbannya berada dalam garis linear kurva kalibrasi yaitu pada konsentrasi 20.144 $\mathrm{mmol} / \mathrm{L}$ untuk ekstrak heksana, $5020 \mathrm{mmol} / \mathrm{L}$ untuk ekstrak etil asetat dan $1078 \mathrm{mmol} / \mathrm{L}$ untuk ekstrak etanol. Hasil perhitungan aktivitas antioksidan ekstrak heksana daun dadap merah adalah $0,680 \mathrm{mmol} / \mathrm{L}$, pada ekstrak etil asetat 5,180 dan ekstrak etanol $10,575 \mathrm{mmol} / \mathrm{L}$. Dari ketiga ekstrak tersebut, ekstrak etanol memiliki aktivitas antioksidan tertinggi kemudian diikuti dengan ekstrak etil asetat, dan ekstrak heksana. Pada penentuan aktivitas antioksidan digunakan asam galat sebagai pembandingnya. Asam galat merupakan salah satu golongan senyawa fenolat yang stabil dan murni, lebih murah, dan kestabilan asam galat tidak hilang lebih dari $5 \%$ apabila disimpan dalam jangka waktu lebih kurang dua minggu di lemari pendingin dan tertutup. ${ }^{13}$ Aktivitas antioksidan ekstrak dibandingkan dengan aktivitas antioksidan asam galat. Dari hasil perhitungan dapat dilihat bahwa aktivitas antioksidan ekstrak lebih rendah dibandingkan dengan aktivitas antioksidan asam galat yaitu $44,323 \mathrm{mmol} / \mathrm{L}$.

\section{KESIMPULAN}

Berdasarkan hasil penelitian yang telah dilakukan, dapat diambil kesimpulan kadar fenolat total ekstrak tertinggi terdapat pada ekstrak etanol daun dadap merah yaitu 5,455 $\mathrm{g} / 100 \mathrm{~g}$ yang juga memberikan aktifitas antioksidan tertinggi sebesar $10,575 \mathrm{mmol} \mathrm{Fe}$ (II)/100 g, namun lebih rendah dari pada aktivitas antioksidan asam galat sebagai pembanding yaitu $44,323 \mathrm{mmol} F e(\mathrm{II}) / 100 \mathrm{~g}$.

\section{DAFTAR PUSTAKA}

1 Hidayat S. Ramuan Tradisional 12 Etnis Indonesia. Penebar Swadaya: Bogor, 2005.

2 Mardosiswojo S, H. Rajakmangunsudarso. Cabe Puyang-Warisan Nenek Moyang I. Balai Pustaka: Jakarta, 1985.

3 Hutapea R. Inventaris Tanaman Obat Indonesia (III). Badan Penelitian dan Pengembangan Kesehatan: Jakarta, 1994.

4 Kahkonen M., .A.I H, H.J V, J.P R, K P, T.S $\mathrm{K}$ et al. Antioxidant Activity of Plant Extracts Containing Phenolic Compounds. Agric Food Chem 1999; : 3954-3962.

5 Umayah EU, M.A.H. Uji Aktivitas Antioksidan Ekstrak Buah Naga (Hylocereus undatus Haw). IImu dasar 2007; : 83-90.

6 Pietta PG. Reviews: Flavonoids as Antioxidant. Journal of Natural Product, 63, 7, 1035-1042. 2000.

7 Cadenas E, Packer L. Handbook of Antioxidant. Marcel Dekker Inc: Switzerland, 2002.

8 Qader SW, Abdullah MA, Chua LS, Najim $\mathrm{N}$, Zain MM, S H. Antioxidant, Total Phenolic Content and Cytotoxicity Evaluation of Selected Malaysian Plants. Molecules 2011.

9 Nurbayani N. Efek Penghambatan Angiogenesis Ekstrak Etanol Daun Tanaman Cangkring (Erythtina fusca Lour) 
Penentuan kadar fenolat total dan aktivitas antioksidan dari ekstrak daun dadap merah (Erythrina fusca Lour) secara Spektrofotometri Uv-Vis

pada Membran Korio Alantois Embrio Ayam Terinduksi bFGF, Skripsi, Fakultas Farmasi, Universitas Gadjah Mada, Yogyakarta. 2003.

10 Fu L, Xu BT, Gan RY, Zhang Y, X X, X R et al. The Phenolic Contents and Antioxidant Capacities of Herbal and Tea Infusions. Int J Mol Sci.

11 Halvorsen BL, Holter K, Myhrstad MCW, Barikmo I, Erlend H, Fagertun RS et al. A systemic Screening of Total Antioxidant in Dietary Plants. J Nutr 2002.

12 RI DK. Departemen Kesehatan RI. 2008.

13 Waterhouse AL. Determination of total phenolic. California: University of California Press. 2002.

14 Vichitphan S, Vichitphan K, P.S. Flavonoid Content and Antioxidant Activity of Krachai-dum (Kaempferia parviflora) Wine. Sci Teh 2007; : 97-105.

15 Mustafa R, Hamid A, Mohamed S, Bakar F. Total Phenolic Compounds, Flavonoids, and Radical Scavenging Activity of 21 Selected Tropical Plants. J Food Sci 2010; : 28-35.

16 Harris DC. Quantitative chemical analysis (7th ed.). New York: W. H. Freeman and Company. 2007. 